\section{R. Barry Farrell}

R. Barry Farrell, 65, professor of political science at Northwestern University for more than thirty years, died on November 11, 1991. Barry Farrell came to Northwestern from Yale in 1957. He was a recognized authority on the Soviet Union and Eastern Europe, the author of Yugoslavia and the Soviet Union, and Political Leadership in Eastern Europe and the Soviet Union.

Barry was a native of Ottawa, Ontario, and first studied at Queens University. His early interest in Canada grew into Northwestern's Canadian Studies Program, which he founded and directed since 1974. Each summer Barry took students to Ottawa, where they worked as interns in parliamentary and ministry offices and took a summer-long course in Canadian politics and culture. He taught a series of research seminars on Canada and was instrumental in Northwestern becoming a Canadian government depository library. His lecture classes on comparative politics regularly drew 200 to 300 students; and he was the recipient of teaching awards from the university and student groups. He wrote more than 100 student recommendations yearly and composed his final midterm exam in the hospital. A dozen of his students were with him when he died; the entire university community mourned his passing.

Wesley G. Skogan

Northwestern University

\section{John H. Hallowell}

John Hamilton Hallowell, James B. Duke Professor Emeritus of Political Science at Duke University, died on August 6 in Manchester, New Hampshire, after a long battle with emphysema. He was 77 and had been living with his wife Sally in retirement in Amherst, New Hampshire.

John Hallowell was born in Spokane, Washington, the son of Harold Atlee Hallowell and Blanche Williams Hallowell. He graduated from Harvard College in 1935, received his masters degree from Duke University and his doctorate from Princeton University.

He taught at Princeton, UCLA, the University of Illinois, the University of North Carolina, Stanford, the University of Munich, and the University of Western Australia. He spent the major part of his career at Duke University, however, where he taught for several decades and where he served as department chair. He served as editor of the Journal of Politics and president of the Southern Political Science Association. He was a recipient of Guggenheim and Fulbright fellowships, and was the Walgreen Foundation lecturer at the University of Chicago in 1952.

Those who were privileged to know him will probably remember him most vividly for his provocative and inspiring teaching of political philosophy. In 1963, he received an honorary Litt. D. degree from the College of Holy Cross. The citation saluted him quite justifiably as a "teacher's teacher" who "inspired by precept and example a whole generation of scholars." None who took his courses will ever forget his captivating presence as a lecturer. $\mathrm{He}$ would pace to and fro, fidgeting with his thick shock of prematurely silver hair, flicking ashes from his cigarette, hitching up his trousers, and laughing with his ready laugh at the foibles and dubious propositions of some of his subjects. He was not neutral in the classroom. He knew that ideas mattered and were not merely intellectual curiosities. He welcomed a good argument, and some of his favorite students were the ones who would rise to the bait and engage him in serious debate. Shortly after his retirement, his former students arranged a dinner in his honor in conjunction with the APSA meeting in Chicago. It was attended by dozens of his students and friends who had a truly memorable and touching evening of warm recollections and tributes to John Hallowell's influence on their professional and personal lives.

As a scholar, John Hallowell wrote The Decline of Liberalism as an Ideology, Main Currents in Modern Political Thought, and The Moral Foundations of Democracy. He also edited Development for What? Prospects for Constitutional Democracy and Eric Voegelin's From Enlightenment to Revolution, and served as general editor of the Lilly
Foundation Research Program in Christianity and Politics. He wrote numerous articles and contributed to several volumes of essays. The formative experience for his intellectual sensibility was, like for many of his generation, the rise of fascism and particularly the rise of Nazism in one of the most advanced and cultured nations in the world. From his study of German philosophy and jurisprudence, he became convinced that the door had been opened to this aberrant form of political life by the deterioration of the ideal of the rule of law from a substantive moral doctrine into pure legal formalism and positivism. His deepest moral and political convictions made him, in effect, the philosophical antithesis of pluralist relativists and postmodern ironists. Liberal democracy, he believed, could not survive and prosper as a mere modus vivendi of morally detached or unserious people. Instead, it must adhere to and base its practices upon a dedication to human dignity, a commitment to justice, and a devotion to the common good. A devout Anglican, Hallowell harbored no illusions that classical and Christian philosophers could be uncritically exhumed and applied to contemporary problems. But he did believe that modern democrats could not ignore the moral insights found there without falling into intellectual error and moral peril.

Although he was not a political activist, he was willing to put himself on the line for his convictions when the occasion presented itself. When he was president of the Southern Political Science Association, he invited Martin Luther King, Jr. to be the keynote speaker at the group's annual convention during the "sitin" demonstration era in a racially uneasy southern city-in the face of counsel that this would not be popular or politic. And he used his prestige and his office as department chair to force his university to fulfill its commitment to integrate its faculty when some wanted to temporize in the face of political pressure.

Some found John Hallowell a forbidding presence. And he could at times be both formidable and severe. One colleague who was an assistant professor under Hallowell's chair- 
manship swears that John fired him four times in one year. But John would always repent on sober second thought, and my colleague is still here. The fact is that beneath the occasionally gruff exterior was a shy and sensitive man actuated by serious and reflective moral passions. He was also a generous friend, husband, and father who could be an uproariously funny raconteur whose best stories were on himself. All of us who were fortunate enough to penetrate the imposing facade will remember him with great warmth and affection.

$\mathrm{He}$ is survived by his lovely and loyal wife Sally, with whom he recently celebrated their golden anniversary, and by three children, four grandchildren, and two great grandchildren.

Thomas A. Spragens, Jr. Duke University

\section{Thomas Page}

Thomas Page died September 4, 1991, in Urbana, Illinois. He graduated from the University of Kansas with a major in economics in 1934. He earned both a master's degree in public administration in 1948 and a doctorate in political science in 1951 from the University of Minnesota.

Professor Page married Barbara Kester at Lawrence, Kansas in 1937. She survives.

After graduating from the University of Kansas, Page worked for the National Bank of Topeka from 1934 through 1941; during the first eight months of World War II, he served as a labor market economist for the U.S. Employment Service for Kansas. In mid-1942, Page volunteered for the Army Air Corps combat glider pilot training program and served as glider instructor until his return to reserve status in November 1945 as a second lieutenant.

Following retirement from active military duty, Page embarked upon an academic career. He was an instructor in political science and research associate in the Bureau of Government Research at the University of Kansas from 1946 to 1948 and an instructor again from 1949 to 1951. In 1951 he accepted a joint appointment in the Department of Political Science and the Institute of Government and Public Affairs at the University of Illinois, UrbanaChampaign. Page was appointed Director, Masters Degree Program in Public Administration, Department of Political Science, University of Illinois, from 1966 until his retirement in 1974. Page was the author of monographs and articles on Kansas politics and Illinois government.

Page was also active in government service. He was a member of the Advisory Board to the Illinois Department of Personnel, 1961-79, and served as a member of the Urbana Civil Service Commission from 1974 until his death. In 1974, the Central Illinois Chapter of the American Society for Public Administration granted him its outstanding achievement award.

A noted pilot in high performance sailplanes, Page was elected to the Soaring Hall of Fame in 1975. He was the faculty sponsor of the Illinois glider club. After retiring from active soaring, he joined the Red Herring Fiction Workshop at the Channing-Murray Foundation, Urbana.

Samuel K. Gove

University of Illinois

\section{Leon H. Weaver}

Leon $\mathrm{H}$. Weaver, a founding member of the Section on Representation and Electoral Systems of the American Political Science Association, died on September 6, 1991, after an illness of several months. An emeritus professor at Michigan State
University, where he joined the faculty in 1960, he was active in the Section until shortly before his death, and he was chairman of the 1991 Section Nominating Committee.

Recipient of a B.S. (1936), M.A. (1938), and Ph.D. (1942) from the University of Illinois, Weaver taught at George Washington University and had a distinguished career in the federal government prior to joining the faculty of Michigan State University. He was an Emergency Planning Consultant with the Office of Civil and Defense Mobilization, Chief of Instruction at the National Civil Defense Training Center, Assistant Secretary of the National Security Resources Board, Secretary to the Policy Committee of the Department of State, and Adviser to the President's Commission on the Administration of Criminal Justice.

His publications include Law and Order Police Training for Civil Defense Emergency, The Civil Defense Debate, Nonpartisan Elections in Local Government, School Consolidation and State Aid in Illinois, and articles in journals and anthologies.

Weaver had a long-standing interest in the fairness of electoral systems and was an observer of elections in other nations. In addition to his own research, he urged others to conduct research on various electoral systems throughout the United States. He was particularly helpful to young scholars by encouraging their research interests. Leon Weaver's wise counsel and assistance will be missed by all who had the good fortune to know him and particularly by those who had the opportunity to work closely with him.

Joseph F. Zimmerman State University of New York at Albany

Bernard N. Grofman University of California, Irvine 